\title{
THE TRADE EFFECTS OF U.S. ANTIDUMPING ACTIONS
}

Thomas J. Prusa

Working Paper 5440

\section{NATIONAL BUREAU OF ECONOMIC RESEARCH 1050 Massachusetts Avenue \\ Cambridge, MA 02138 \\ January 1996}

The author is indebted to Rob Feenstra for assistance in constructing the data set and to Bob Staiger and the seminar participants at the NBER conference on the Effects of U.S. Trade Protection and Promotion Policies for their helpful comments. This paper is part of NBER's research program in International Trade and Investment. Any opinions expressed are those of the author and not those of the National Bureau of Economic Research.

(C) 1996 by Thomas J. Prusa. All rights reserved. Short sections of text, not to exceed two paragraphs, may be quoted without explicit permission provided that full credit, including (c) notice, is given to the source. 


\title{
THE TRADE EFFECTS OF U.S.
}

ANTIDUMPING ACTIONS

\begin{abstract}
In this paper I present evidence on the effectiveness of $\mathrm{AD}$ actions. Using a data set based on the line-item tariff codes identified in the cases, I examine the trade patterns of both countries named in the petition and those countries not subject to the investigation. Several important findings emerge. First, $\mathrm{AD}$ duties substantially restrict the volume of trade from named countries, especially for those cases with high duties. Second, AD actions that are rejected still have an important impact on named country trade, especially during the period of investigation. Third, there is substantial trade diversion from named to non-named countries and the diversion is greater the larger is the estimated duty. Because of the diversion of imports, the overall volume of trade continues to grow-even for those cases which result in duties. Fourth, despite the diversion of imports, $A D$ law still offers important benefits because it induces substantial import price increases both by named and non-named countries. Finally, because of the diversion of imports, aggressive use of $\mathrm{AD}$ law by U.S. firms has the peculiar side-effect of benefiting non-named countries who are active in the areas under investigation.
\end{abstract}

Thomas J. Prusa

Department of Economics

New Jersey Hall

Rutgers University

New Brunswick, NJ 08903-5055

and NBER 


\section{Introduction}

Even though tariff rates fell throughout the late-1970s and 1980s, there is growing consensus that the overall level of protection in the U.S. rose during this period. For instance, Bhagwati (1988) states "the downward trend in trade restrictions resulting from declining tariffs was rudely interrupted in the mid-1970s (p. 43)" and Nivola (1993) points out that between 1975 and 1985 the volume of U.S. import trade affected by some form of trade barriers has doubled. In fact, from a historical perspective what is surprising is not that the long post-war period of trade liberalization was interrupted (at least temporarily) but that the era of trade liberalization lasted so long.'

Rather, what is unusual about the recent rise in protectionism is the form in which it has taken. In earlier years, increased demand for protection was met with comprehensive tariff bills. By contrast, the recent rise in protection is almost entirely due to administered protection and non-tariff barriers such as voluntary export restraints (VERs) which differ in several important ways from traditional tariff protection. First of all, the modern tools of protection are typically more subtle and less transparent than tariffs, falling in the grey area between GATT-consistent and GATT-inconsistent protection. This ambiguity explains why the modern tools are so popular since it allows countries considerable discretion over when and how to implement these policies. Is a health standard that outlaws the sale of beef from cattle injected with growth hormones truly based on a public safety concern or is it simply an attempt to reduce the amount of imported beef? Are budget cuts that significantly reduce the staff at customs offices a sincere effort to manage the federal deficit or a veiled attempt to raise the cost of exporting into the U.S. market? Are an industry's fall in profits and sales due to the increasingly efficient foreign competitors or is this injury due to dumped imports?

\footnotetext{
${ }^{I}$ For most of U.S. history, periods of trade liberalization were quite short-lived, typically only five or six years long (Taussig. 1931).
} 
A second key characteristic-and the one that is the focus of this paper-is that the modern instruments are usually not comprehensive. Protection via VERs and the unfair trade statutes is product- and country-specific. For instance, the 1981 automobile VER with Japan neither restricted autos from South Korea nor (initially) restricted light trucks or utility vehicles from Japan. One might expect that the restriction on Japanese autos would lead to an increase in the imports of Japanese trucks and utility vehicles and South Korean autos. ${ }^{2}$ Similarly, an antidumping (AD) duty levied on carbon steel pipes from France is not levied on carbon steel pipes from Germany. One would expect that an antidumping duty levied on a single source, would cause exports from the named country (i.e., France) to fall and those from non-named countries to increase.

The goal of this paper is to begin to address the issue of how the country-specific nature of $\mathrm{AD}$ protection affects its use and effectiveness. I find evidence that $\mathrm{AD}$ protection induces substantial trade diversion from named to non-named countries. There is also evidence that the larger is the estimated duty, the larger is the amount of diversion. Because the magnitude of import diversion is found to be quite large, the results also suggest that AD duties are less restrictive than the domestic industry might expect. Nonetheless, AD duties are valuable since trade is restrained by more in cases resulting in duties than in cases that are rejected. More generally, AD actions are valuable since they induce substantial import prices increases-both by named and also by non-named countries.

The paper will proceed as follows. In the next section I provide background to the rise of U.S. AD activity and discuss related research. In section 3 I present data on the trade effects of AD actions with particular emphasis on the magnitude of import diversion from named to nonnamed countries. Given that we find import diversion to be substantial, the U.S.'s aggressive use of $\mathrm{AD}$ law has a peculiar side-effect-non-named countries who are active in the categories

\footnotetext{
${ }^{2}$ See Feenstra $(1984,1987)$ and Dinopoulos and Kreinin (1988) for analysis of the VER on Japanese autos.
} 
under investigation (but not named) will benefit from the AD sanctions on rivals. In other words, the diversion of imports implies that domestic producers are not the only firms who benefit from an $\mathrm{AD}$ action. Countries such as South Korea and Brazil, both who are frequently named in AD petitions, may nevertheless be net beneficiaries of $\mathrm{AD}$ actions since they also gain from sanctions on other countries. This issue of which countries' trade have contracted the most and which have expanded the most as a result of U.S. AD actions is discussed in section 4. A few concluding comments are made in section 5.

\section{Background}

THE RISE OF AD LAW

During the 1980s there were more AD cases filed (almost 500) than all of the other trade statutes combined (Baldwin and Steagall, 1994; Hansen and Prusa, 1995a). AD law, however, is far from an overnight sensation. In fact, $\mathrm{AD}$ law is one of the oldest of U.S. trade statutes. The emergence of $\mathrm{AD}$ law as the preeminent trade statute is the result of many revisions and amendments over the years; the vast majority of the amendments were geared at expanding its applicability and increasing the likelihood of an AD case resulting in duties. Prior to 1958, for instance, AD actions were extremely rare. Then in 1958 Congress amended the rules governing the how the dumping margin was calculated and petition filings increased: about 20-25 petitions were filed per year between 1958 and 1973; however, the rejection rate was quite high (on average only two or three cases per year would result in duties). In 1974, AD law was again significantly amended: the definition of dumping was broadened to include sales below cost and strict time limits on the length of the investigation were imposed. Following the 1974 amendments, AD filings jumped by $50 \%$. Despite these changes, the rejection rate remained around $85 \%$.

Frustrated by the lack of protection afforded by the law, industries lobbied Congress to make 
the law more likely to result in duties. These lobbying efforts were manifested in the Trade Agreement Act of 1979 which contained numerous significant changes to AD law. Among them: the power to investigate less than fair value was transferred from the Department of Treasury to the Department of Commerce, use of "best information available" was approved, time limits on cases were shortened. As a result of these amendments, the use of AD law, exploded. During the years following these amendments, AD filings surged, averaging 45-50 cases per year, and the rejection rate dropped to about $50 \%$.

The point of this historical background is to emphasize that $\mathrm{AD}$ is a malleable, frequently amended statute. AD law is now the most widely used trade statute primarily because Congressional amendments have made the statute far more applicable than it was in the 1960s and 1970s. The kinds of pricing behavior that are sanctionable under AD have changed over the years. And importantly, usually these changes are in response to complaints from U.S. industries who find the current implementation of the law unsatisfactory. One would expect then, that the countryspecific nature of AD protection be a prime target for change. However, GATT guidelines prevent Congress from amending AD law to apply to imports from all sources.

A more creative solution was needed and the "cumulation" amendment contained in the Trade and Tariff Act of 1984 is a significant step in the direction of making AD protection more comprehensive. The cumulation provision requires the ITC to cumulate imports when a trade dispute involves imports from multiple sources. Without cumulation, imports are evaluated on a country-by-country basis when determining injury; when cumulation is applied the International Trade Commission (ITC) aggregates all "like" imports from all countries under investigation and assesses the combined impact upon the domestic industry.

When Congress was debating whether to mandate cumulation, the issue of diversion was never mentioned. Rather, the stated reason for the amendment was that the source of the dumped or subsidized imports was irrelevant. What mattered was that the cumulated volume was injuri- 
ous. This argument in favor of cumulation has been referred to as the "hammering effect," since according to industries and their representatives,

... a domestic industry that suffers material injury by reason of 100,000 tons of unfairly traded imports from a single country is injured to the same degree by 20,000 tons of unfairly traded imports from each of five different countries (Suder, 1983).

The main goal of mandated cumulation was to reduce the rejection rate at the ITC. Hansen and Prusa (1995b) find that this has indeed been the result; they estimate that cumulation increases the probability of an affirmative injury determination by $20-30 \%$ and has changed the ITC's decision (from negative to affirmative) for about one-third of cumulated cases.

Cumulation may also have important implications for import diversion. For instance if (i) cumulation increases the number of multiple petition filings and (ii) the greater the number of countries named in the petition, the less significant will be the import diversion, then cumulation will effectively make $\mathrm{AD}$ law more comprehensive. The first part of the hypothesis is clearly correct, since during the years following mandated cumulation there has been a 50\% in the multiple petition filings. The second part of the hypothesis is an issue we will want to examine in this paper (i.e., is diversion less important when more countries are named).

\section{RELATED RESEARCH}

The popularity of AD law has spurred a large body of literature, both theoretical and empirical, but none has focused specifically on the issue of diversion. The theoretical research on AD law has focused on its strategic and incentive effects. ${ }^{3}$ Broadly speaking, the empirical literature on

\footnotetext{
${ }^{3}$ Depending on the precise model specification, AD law can induce a rich variety of strategic effects. For example, in Anderson (1992) the threat of an AD duty induces foreign firms to behave more competitively, while in Staiger and Wolak (1991), Leidy (1993), and Prusa (1994) AD law can facilitate collusion. Fischer (1992) points out that the nature of the strategic competition influences how $A D$ law affects competition.
} 
AD law can be divided into two groups. One line of research is based on Baldwin's (1985) seminal work on the determinants of administered protection. ${ }^{4}$ Another group of papers empirically estimate the effects of antidumping cases. ${ }^{5}$ However, a shortcoming to virtually all of the empirical papers is that estimates are based on aggregated data, typically four digit SIC industry data. For example, Lichtenberg and Tan (1990) estimate the effects of AD cases, but their estimates are for all SIC level imports (i.e., from all source countries). Given that AD protection is country-specific, their aggregated approach will not measure the important trade creation and diversion that are a fundamental characteristic of $\mathrm{AD}$ protection.

An important exception is Krupp and Pollard (1992) who examine the effects of AD actions in the chemical industry using monthly TSUSA level import data. Their use of disaggregated data allows them to examine the effect of AD actions for the chemical industry. However, since Krupp and Pollard collect disaggregated data for only a single industry they are not address the general issue of diversion.

Staiger and Wolak (1994) also control for the aggregation issue caused by using SIC level data by normalizing SIC level imports with the number of TSUSA codes under investigation in each SIC category. Staiger and Wolak estimate trade effects of AD investigation with particular emphasis on the filing and investigation effects. Even though their estimates are based on SIC data, Staiger and Wolak are still able to find evidence of import diversion, and in general find that the restraint on overall imports is about one-third to one-half as much as on imports from the named country.

\footnotetext{
${ }^{4}$ Moore (1992), Baldwin and Steagall (1994), and Hansen and Prusa (1995b) all focus on the determination of International Trade Commission decisions. A large number of other related papers are cited in these papers.

${ }^{5}$ Work in this area includes Finger, Hall, and Nelson (1981), Harrison (1991), Hartigan, Kamma, and Perry (1989).
} 


\section{The Trade Effects of AD Actions}

\subsection{ThE DATA}

In order to examine the trade effects of AD cases, time series trade data for each AD case needed to be constructed. To do this, I collected the line-item tariff codes named for each of the 428 AD petitions filed between 1980 and 1988. The product codes and the estimated AD duty are found the Federal Register notices accompanying each determination made by the Department of Commerce and ITC.

Until 1988 products were usually identified by their 7-digit Tariff Schedule of the U.S.A. (TSUSA) code. In a significant number of cases the products were identified by their 5-digit TSUSA code. Because of this difference, and in order to reduce the missing values due to the numerous changes in the TSUSA codes, I aggregated all 7-digit codes to their 5-digit equivalent. In 1989 the U.S. adopted the Harmonized Tariff Schedule (HTS). Therefore in order to extend the time series beyond 1988 the TSUSA codes were concorded with their corresponding HTS codes. Once the TSUSA codes were collected, import trade data for those products under investigation were extracted from the Commerce Department's annual import trade data by source country. Imports were deflated using the GNP price deflator. Time series for the products involved in each case were constructed from 1978 to 1993.

Other work has shown that settled cases can have a significant impact on trade (Prusa, 1992; Staiger and Wolak 1994). However, to narrow the analysis I chose to exclude settled cases in the present analysis and thus compare import diversion in cases that are rejected with diversion in those that result in duties. After dropping cases where only incomplete data series could be constructed the data set is comprised of 109 rejected cases and 126 cases where duties were levied. ${ }^{6}$

\footnotetext{
${ }^{6}$ Incomplete data series can arise if a product's TSUSA code changes (so only partial time series could be constructed) or the TS-HTS concordance is unsatisfactory.
} 
The diversity of $\mathrm{AD}$ cases complicates matters since trade volume in some cases amounts to only a few million dollars while in others the trade volume is in the hundreds of millions of dollars. To control for these vast differences, I plot all variables as percentage changes relative to their value in the year the petition was filed $\left(\right.$ year $\left.t_{0}\right) .{ }^{7}$ The year following the petition is denoted $t_{1}$, the year after that, $t_{2}$, etc. Except under unusual circumstances the case must be decided within one year, and so during year $t_{1}$ imports are being investigated.

\section{Filing Behavior: A Look at the Countries InVEstigated}

The set of countries subject to $\mathrm{AD}$ investigations between 1980 and 1988 is comprehensive: over 50 countries representing all major U.S, trading partners were subject to investigation. The bulk of cases were against developed countries and the export-oriented growth countries such as South Korea and Taiwan, but countries as small as Trinidad and Tobago, Bangladesh, and Iran were also subject to $\mathrm{AD}$ investigations. In Table 1 the countries most frequently named in $\mathrm{AD}$ petitions are listed. As is readily apparent, the countries at the top of the list constitute virtually all important U.S. trading partners.

In addition, I include the percent of each country's cases resulting in duties. Between 1980 and 1988 about one-third of AD petitions resulted in duties, one-third in settlements, and onethird were rejected. In general, the countries appearing on this table are representative of the general incidence of duties. In the final column I give information about the number of cases where the listed country was active in an import market that was subject to an $\mathrm{AD}$ investigation, but where that country was not named. For instance, Japanese industries were named as an alleged dumpers in 52 cases, of which 17 (33\%) resulted in duties. In 112 other AD cases, Japan exported to the U.S. market but was not the country subject to investigation. As will be

\footnotetext{
${ }^{7}$ I also adjusted the trends for macroeconomic trends by measuring relative to changes in overall merchandise trade. The results are qualitatively the same as those presented here and are available upon request.
} 
discussed in section 4 , in these cases Japanese firms potentially stood to benefit from U.S. AD actions. If $\mathrm{AD}$ duties are levied, some other country (a rival) would be subject to duties thereby giving Japanese firms an opportunity to expand their sales in the U.S. market.

\section{NAMED COUNTRY IMPORTS}

The first issue is the effect of $\mathrm{AD}$ actions on imports from the named country. In Figure $1 \mathrm{I}$ present changes in the value of imports. The trends look as one would have expected. On average when duties are levied trade from the named country is restricted, especially in comparison to when the case is rejected. In year $t_{1}$ import trade from the named country (when duties are levied) was $9 \%$ less than it was in $t_{0}$, and $16 \%$ less than import trade from named countries in rejected cases. In year $t_{2}$ import trade from the named country (when duties are levied) was $25 \%$ less than trade in rejected cases. While these numbers suggest that $\mathrm{AD}$ duties have a substantial impact on trade, at least from the named country, it should be noted that the largest restriction appears to occur in the very short-run. By $t_{2}$ trade from the named country (when duties are levied) is already rebounding and by $t_{3}$ trade exceeds its pre-petition level.

The size of the duty plays a key role in the how restrictive an $\mathrm{AD}$ case is. In Figure $1 \mathrm{I}$ also compare those cases that are subject to duties in the top quartile (i.e., duties greater than $36 \%$ ) with those subject to duties in the bottom quartile (i.e., cases with positive duties, but less than 7\%). For these two sets of cases the restrictive effect of AD actions is more marked. For instance, we find that import trade from the named country falls by $47 \%$ during the first year for countries subject to very high $\mathrm{AD}$ duties. By contrast, cases subject to small duties apparently experience no perceptible decline in import trade - and in fact imports grow by almost $10 \%$ during the first year following the petition.

While it seems surprising that named imports would grow when duties are levied, this result highlights a unique characteristic of $\mathrm{AD}$ protection. If an $\mathrm{AD}$ duty is levied and the named 
country raises its U.S. market price by the full amount of the duty (holding home market prices constant), the assigned duty will never in fact have to be paid. In this case, the AD duty serves to create a price floor for the named country's products. This characteristic likely is part of the explanation for why small duties might be beneficial for the named country. The other key reason is the fact that firms competing noncooperatively typically find that competition forces them to cut their price, and if they could somehow reduce the incentive to undercut their rivals, they would benefit from higher prices. Since AD duties are essentially government mandated price floors and since small duties will raise the named country's AD-distorted price only slightly higher than the original prices, it might easily be the case that the primary effect of $A D$ duties is the creation of desirable coordination benefits.

It is also instructive to look at imports from named countries in high and low duty cases when duties are not levied. In Figure 2 I depict trade patterns for rejected AD cases. What is interesting is that the even when duties are never levied, imports often fall during the investigation. For instance, cases threatened with high duties (but are ultimately rejected) find that trade from the named country falls by almost $20 \%$ during the investigation. This finding is consistent with Staiger and Wolak's (1994) finding that there is a substantial "investigation" effect to an $\mathrm{AD}$ petition. It is not surprising that the investigation effect is most apparent for high duty cases. This effect stems from the fact once the Commerce Department makes its preliminary duty calculation, duties are collected (as a bond) pending the final outcome of the investigation. If the case is ultimately rejected the bond is returned. But during the investigation, the required bonding creates considerable uncertainty as to the true price of the goods. Once the case is resolved the uncertainty is resolved and the investigation effect disappears: imports from named countries (especially those in high duty cases) rebound sharply. 


\section{IMPORTS FROM NON-NAMED COUNTRIES}

Even though successful AD actions restrict imports from the named country, the countries who are not subject to the investigation can offset this restraint by increasing their sales to the U.S. This potential diversionary effect of $\mathrm{AD}$ actions is indeed observed. In Figure 3 the value of imports from non-named countries is depicted. The diversion of trade is large, not only when duties are levied but also when the case is rejected. In fact, surprisingly we find that diversion is even more substantial when duties are not levied.

On average, imports from non-named countries grow by $22 \%$ in year $t_{1}$. In addition, we find that the diversion is greater for high duty cases than for low duty cases. This pattern makes sense given that we saw in Figures 1 and 2 that the AD actions have a more substantial impact on the named country's imports in high duty cases than in low duty cases. For cases where high duties are imposed, non-named countries increase their imports $30 \%$ by year $t_{2}$, and $40 \%$ by year $t_{3}$. Diversion is still substantial when low duties are levied, averaging $15-20 \%$ during each of the first three years following the petition.

In Figure 4 we again depict imports from non-named countries when duties are levied, but here we control for the number of countries named in the petition. As should to be expected, diversion is more substantial when only a single country is named. In the first year following a petition non-named imports grew by $35 \%$ when a single country was named as compared the $4 \%$ growth when more three or more countries are named. This pattern in the amount of diversion persists throughout the years following the case.

\section{OVERALL IMPORTS}

In Figure 5 the effect on imports (in the investigated product categories) from all source countries is depicted. Two trends emerge. First, the trade impact of AD actions is far less substantial for 
overall imports than for imports from the named country. For instance, in year $t_{1}$ imports from the named country fall by $11 \%$ when duties are levied. At the same time (year $t_{1}$ ), however, overall imports increase by $15 \%$. In year $t_{2}$ imports from the named country are still down $9 \%$, but overall imports increase by $11 \%$. Interestingly, a similar pattern emerges for cases that are rejected. For example, imports from the named country increase by $5 \%$ in year $t_{1}$ but overall imports increase by $19 \%$. Clearly, the ability of non-named countries to increase their imports destined for the U.S. softens the restrictions imposed by AD duties. Second, diversion does not imply that $\mathrm{AD}$ duties have no effect on overall import trade. Overall import growth for cases where duties are levied is about 5-10 percentage points less than for rejected cases during the first few years following the $\mathrm{AD}$ petition. Taken together, these results indicate that attempts to understand the impact of $\mathrm{AD}$ actions will surely fail if one only looks the effects on import trade from the named country. While $\mathrm{AD}$ duties do reduce the overall import growth, the effect is more muted than the reduction to imports from the named country.

In Figure 6 we focus only on cases where duties are levied and again examine imports from all source countries. But the difference here is that we control for the number of countries named in the petition. In Figure 4 we saw that there is less diversion when three or more countries were named. By contrast, here we see that overall impact on imports are not so systematically impacted by the number of named countries. During the first two years following the filing, petitions with at least three named countries do appear to have very little import growth, but thereafter overall imports grow more rapidly than in petitions with only a single country. While it is not clear why this is the case, it does reinforce the notion that looking only at the effect of $\mathrm{AD}$ on the named country will surely be misleading. 


\section{The EFFect on Unit Values and Quantities}

Underlying the changes in imports are changes in prices (unit values) and quantities. In Figure 7 the effect of $\mathrm{AD}$ actions on unit values (as charged by the named country) are depicted. The results are precisely what one would expect. Unit value rise more for cases resulting in duties than for cases that are rejected. For instance, by year $t_{3}$ unit values when duties are levied have risen more than twice as much as cases without duties. In addition, unit value rise more quickly for cases with high duties than for cases with low duties. For instance, by year $t_{3}$ unit values for cases with the highest duties have risen by more than $100 \%$ since the case was filed; by contrast, in the same period of time, unit values for cases with the lowest duties have risen by about $40 \%$.

Figure 8 depicts the quantity effect of AD duties. Again, the results are exactly what one would expect to find. We see that quantities fall by more (i) when duties are levied than when the case is rejected and (ii) when high duties are levied than when low duties are levied.

Combining the results depicted in Figures 3, 7, and 8 we have a set of patterns that are consistent with the conjecture that $\mathrm{AD}$ cases which result in low duties serve as a facilitating practice. Cases with low duties still experience import growth, rising prices, and increasing quantity of sales. Recall that "low duty" cases are defined as having AD duties less than 7\%. Remember also that unlike tariffs, the named country can avoid paying AD duties if it raises its U.S. prices by the full duty amount. A mandated price floor that is only a small amount greater than current prices could easily allow all the foreign firm to price more like a Stackelberg leader. It is reasonable to believe that the U.S. industry benefits from higher prices by foreign firms, and therefore in this scenario the $\mathrm{AD}$ provides coordination benefits for the rivals.

In a typical model of strategic interaction other firms in the market respond to price increases by one party. We would expect to observe such strategic interactions in response to AD induced price changes. In Figure $9 \mathrm{I}$ depict the unit values for the named country and also for non-named 
countries. (For each case, the non-named country's unit value was calculated using a weighted average of the individual countries' imports.)

The results again are clearly consistent with what would be predicted by theory: as the named country's unit values increase, the non-named countries' unit values increase, but in general by a somewhat smaller amount (60-70\% of the named country's change). This trend is found both when cases are rejected and also when cases result in duties. This is consistent with the notion price effects of AD investigation cascade to non-named countries. In this respect, AD law is quite effective. The price increases induced by an $\mathrm{AD}$ action spur price increases by other foreign rivals.

Finally, in Figure 10 the effect of duties on unit values are depicted controlling for the number of countries named in the petition. Certainly in the short-run it appears that the number of named countries does not significantly effect the price increases induced by duties. However, in the longer run (greater than three years) it does appear to matter.

\section{ESTIMATION RESULTS}

In Table 2 I present OLS regression results for named imports, non-named imports, and overall imports. The basic specification is

$$
\begin{aligned}
\ln x_{i, t_{j}}=\alpha & +\beta_{0} \ln x_{i, t_{-1}}+\beta_{1} \ln \left(x_{i, t_{-1}} / x_{i, t_{-2}}\right)+\beta_{2} \text { NumNamed }_{i}+\beta_{3} \ln \text { Duty }_{i} \\
& +\beta_{4}\left(\text { Dec }_{i} \ln \text { Duty }_{i}\right)+\beta_{5} t_{j}+\beta_{6}\left(t_{j} \text { Dec }_{i}\right)+\beta_{7} \text { Year }_{t_{j}}, \quad j=0, \ldots, 5 .
\end{aligned}
$$

The variable $x_{i, t_{j}}$ denotes imports for case $i$ at time $t_{j}$, where $t_{0}$ corresponds to the year the petition was filed, $t_{1}$ to the period of investigation, and $t_{2}$ through $t_{5}$ are the years following the outcome. The variable Duty ${ }_{i}$ denotes the size of the duty. ${ }^{8}$ Given our earlier discussion we might expect the

\footnotetext{
${ }^{8}$ Recall that even if a case is ultimately rejected, a duty level is estimated by the Commerce Department. Until the final ITC injury determination duties are collected (as a bond) pending the final outcome of the investigation. If
} 
number of countries named $\left(\right.$ NumNamed $\left._{i}\right)$ to have an effect $(=1$ when three or more countries are named). The variable $\operatorname{Dec}_{i}$ is a decision dummy (=1 if duties are levied). Calendar year dummies $\left(\right.$ Year $\left._{i_{j}}\right)$ are included in the estimation to control for macroeconomic trends.

A number of the general trends depicted in the figures are also emerge from the regressions. Consider first the effect on imports from the named country. The estimated duty effect is negative and significant. The restriction when duties are levied $(-0.158=-0.055-0.103)$ is about three times as large as the restriction stemming from the investigation effect alone $(-0.055)$. Results from an alternative specification where a dummy variable is used to capture the duty effect are also reported. In this specification the restriction from low and high duties are estimated (relative to moderate duties). Notice that low duties appear to have little impact on import trade, especially if the case does not result in duties. This result is consistent with the notion that main effect of small AD duties is beneficial coordination. On the other hand, high duties have a large negative impact on imports, especially when duties are levied. Second, note that in both specifications the impact of an AD investigation is quite long lived. The time effects are negative and quite large, although most are insignificantly estimated.

The results for non-named imports help characterize the amount of import diversion. Broadly speaking, the results are consistent with the trends depicted in the figures. We find, for instance, that diversion is greater for cases that are rejected (the time-decision cross-effect coefficients are all negative). We also find that the larger the duties, the more diversion there is, especially for rejected cases. Interestingly, we find that after controlling for other effects, diversion seems to increase in the number of countries named, a result that bears further study in future work.

The results for overall imports suggests that import diversion mitigates most, if not all, the impact of $\mathrm{AD}$ actions on the value of imports. For instance, note that overall imports increase in cases where no duties are levied. The time effect dummies are all positive. However, overall the case is ultimately rejected the bond is retumed. 
imports do fall for cases that result in duties: the estimated decision-duties and decision-time cross-effects are all positive. On net, AD duties do cause overall imports to fall, but the restriction is far less than the restriction to named country imports.

\section{Net Country Effects of U.S. AD Actions}

Interestingly, the import diversion induced by $\mathrm{AD}$ actions implies that many foreign countries benefit from the U.S.'s aggressive use of AD law. On average, it seems reasonable to believe that countries who are named will tend to lose from AD actions, while those who are not named will in general benefit. Thus, although the countries listed in Table 1 were all frequently subject to AD investigations, they were also active in many product categories where some other country was subject to $\mathrm{AD}$ investigation. Paradoxically, the main benefactors of $\mathrm{AD}$ duties may not be the U.S. complainant, but rather the other countries competing in the U.S. market. If import diversion were complete and the price effects small, the U.S. industry which spent hundreds of thousands of dollars (if not millions) assembling the forms, mobilizing disparate firms to provide information, lobbying Congressmen, and all the other sundry expenses associated with filing a petition, might receive little or no gain.

Using the estimates reported in Table 2 we can measure the effect of AD duties. In particular, when a country is named we can estimate the value of imports with the duty and also what imports would have been if duties had never been levied. The difference is the effect of AD duties for the named country in that case. If we sum the trade effects over all cases where a country was named, a measure of the AD duties induced trade contraction can be constructed.

Similarly, using the estimates on non-named imports we can estimate the value of non-named imports with the duty and also what non-named imports would have been if duties had never been levied. The difference is the effect of AD duties for the non-named country. Summing over all 
non-named countries would yield the total diversion for that case. If we sum the trade diversion over all cases where a country was not named (but was actively exporting to the U.S.), a measure of the AD duties induced trade expansion can be constructed.

In Table 3 I report the results from performing such calculations using the changes in imports between $t_{0}$ and $t_{1}$ as the measure of the trade effect. Clearly this measure does not capture all trade effects of $\mathrm{AD}$ actions since it does not control for what trade patterns would have been without any $\mathrm{AD}$ activity, but it nonetheless highlights the idea that the distortions caused $\mathrm{AD}$ law can either be a blessing or a curse. ${ }^{9}$

In the upper part of the table I list the countries who have suffered the greatest trade contraction when named in U.S. AD actions (and subject to duties). Japan, the most frequently named country, easily tops the list as the country whose trade has fallen the most as a result of U.S. AD duties (total estimated losses of $\$ 7.6$ billion). Note, however, that we estimate that Japan's exports to the U.S. increase by more than $\$ 5$ billion, yielding a net trade contraction of about $\$ 2$ billion. The other countries on the list all suffer sizeable import losses (when named), but far less than Japan. It is interesting to note that all of the remaining countries, except Iran, are estimated have a net gain in trade with the U.S. despite their losses in cases where duties were levied. Of particular interest is that fact that Canada is estimated to be a net gainer from AD duties. Given the highly visible nature of many Canadian-U.S. AD disputes, this is somewhat surprising finding. However, it does serve as a reminder that politics rather than economics are often more important in explaining the tensions created by a trade suit.

In the bottom part of the table I list the 10 countries who experience the greatest trade expansion as a result of U.S. AD actions. All of the countries on this list are estimated to experience a net gain of over $\$ 20$ billion as a result of duties being levied on other countries.

\footnotetext{
${ }^{9}$ In addition, the calculation does not include any of trade distortions from that cases that were settled.
} 


\section{Concluding Comments}

Overall, the evidence presented in this paper suggests that the protection offered by AD law is significantly offset by the ability of alternative foreign suppliers to increase their shipments destined for the U.S. Even though imports from named countries are restricted, especially for those cases with high duties, most of the protective effect of AD duties are offset by the increased trading activity of non-named countries.

The results also suggest that the country-specific nature of $\mathrm{AD}$ protection is an important factor in explaining both the surge in $\mathrm{AD}$ actions during the 1980s and also in evaluating the protective effect of AD actions. In conjunction with previous work on the effect of the cumulation amendment (Hansen and Prusa, 1995b), the results in the paper are consistent with the view that the surge in AD filings during the 1980s is strategic attempt to compensate for the limited nature of $\mathrm{AD}$ protection and is not evidence of an increase in injurious pricing by foreign competitors.

The fact that almost 300 AD cases have been filed during the first half of the 1990s leaves little doubt that U.S. firms will continue to frequently use AD law to reduce import competition. This results in this paper suggest that unless the popularity of multiple petition filings increases the overall share of imports investigated, the other foreign suppliers will mitigate the losses caused by AD protection.

\section{References}

Anderson, James E. 1992. “Domino Dumping, I: Competitive Exporters," American Economic Review 82 (March) 65-83.

Baldwin, Robert E. The Political Economy of U.S. Import Policy. Cambridge: MIT Press, 1985. 
Baldwin, Robert E. and Jeffrey W. Steagall. "An Analysis of ITC Decisions in Antidumping, Countervailing Duty and Safeguard Cases." Weltwirtschaftliches Archiv, 130(2), 1994, 290_ 308.

Bhagwati, Jagdish. (1988) Protectionism. Cambridge, MA: The MIT Press.

Dinopoulos, E. and M. Kreinin. 1988. "Effects of the U.S.-Japan VER on European Prices and on U.S. Welfare." Review of Economics and Statistics 70(3), August, 484-91.

Feenstra, R. 1984. "Voluntary Export Restraint in U.S. Autos, 1980-81: Quality, Employment, and Welfare Effects." in R.E. Baldwin, ed. The Structure and Evolution of Recent U.S. Trade Policy. Cambridge: University of Chicago Press.

Feenstra, R. 1987. "Gains from trade in differentiated products: Japanese compact trucks." in R. Feenstra, ed. Empirical Methods for International Trade. Cambridge: MIT Press.

Finger, J. Michael, H. K. Hall, and D. R. Nelson. "The Political Economy of Administered Protection." American Economic Review, June 1982, 452-66.

Fischer, Ronald D. [1992], "Endogenous Probability of Protection and Firm Behavior," Journal of International Economics 32, 149-163.

Hansen, Wendy L. and Thomas J. Prusa. 1995a. "The Road Most Taken: The Rise of Title VII Protection." The World Economy, March, 295-313.

Hansen, Wendy L. and Thomas J. Prusa 1995b. "Cumulation and ITC Decision-Making: The Sum of the Parts is Greater Than the Whole," forthcoming Economic Inquiry.

Harrison, Ann. 1991. "The New Trade Protection: Price Effects of Antidumping and Countervailing Duty Measures in the United States." World Bank working paper.

Hartigan, James C., Sreenivas Kamma, and Phillip R. Perry. 1989. “The Injury Determination Category and the Value of Relief from Dumping." Review of Economics and Statistics. 71 
(February): $183-86$

Krupp, Corinne M. and Patricia S. Pollard. 1992. "Market Responses to Antidumping Laws: Some Evidence from the U.S. Chemical Industry," unpublished manuscript, Michigan State University.

Leidy, Michael P. 1993. "Quid Pro Quo Restraint and Spurious Injury: Subsidies and the Prospect of CVDs," in Alan Deardorff and Robert Stern (eds.), Analytical and Negotiating Issues in the Global Trading System, Ann Arbor: University of Michigan.

Lichtenberg, Frank and Hong Tan. 1990. “An Industry Level Analysis of Import Relief Petitions Filed by U.S. Manufacturers, 1958-85," mimeo.

Moore, Michael, "Rules or Politics? An Empirical Analysis of ITC Antidumping Decisions." Economic Inquiry, July 1992, 449-66.

Nivola, Pietro S. 1993. Regulating Unfair Trade The Brookings Institution, Washington, D.C.

Prusa, Thomas J., "Why are so many antidumping petitions withdrawn?, Journal of International Economics, 33 (1992) 1-20.

Prusa, Thomas J. 1994 "Pricing Behavior in the Presence of Antidumping Law," Journal of Economic Integration, 9(2), 260-289.

Staiger, Robert W. and Frank A. Wolak [1991], "Strategic Use of Antidumping Law to Enforce Tacit International Collusion," unpublished manuscript, Stanford University.

Staiger, Robert W. and Frank A. Wolak. 1994. "Measuring Industry-Specific Protection: Antidumping in the United State," Brookings Papers on Microeconomics, 51-118.

Suder, Jonathan T. "Cumulation of Imports in Antidumping and Countervailing Duty Investigations." George Washington Journal of International Law and Economics, 17, 1983, 463-87.

Taussig, Frank. 1931. A Tariff History of the United States 8th edition. New York: A.M. Kelley. 
Table 1

Countries Most Frequently Named in AD Investigations

\begin{tabular}{|c|c|c|c|}
\hline Country & $\begin{array}{l}\text { \# Cases } \\
\text { Named }\end{array}$ & $\begin{array}{c}\% \text { Cases resulting } \\
\text { in duties }\end{array}$ & $\begin{array}{l}\text { \# cases exporting to U.S. } \\
\text { but not named }\end{array}$ \\
\hline $\begin{array}{l}\text { Japan } \\
\end{array}$ & 52 & $33 \%$ & 112 \\
\hline Taiwan & 26 & $46 \%$ & 115 \\
\hline West Germany & 25 & $56 \%$ & 122 \\
\hline Italy & 25 & $40 \%$ & 139 \\
\hline Canada & 24 & $50 \%$ & 142 \\
\hline Brazil & 23 & $30 \%$ & 108 \\
\hline South Korea & 23 & $39 \%$ & 109 \\
\hline France & 21 & $38 \%$ & 136 \\
\hline United Kingdom & 17 & $47 \%$ & 145 \\
\hline Belgium & 16 & $44 \%$ & 131 \\
\hline P.R. China & 16 & $31 \%$ & 94 \\
\hline Spain & 14 & $21 \%$ & 115 \\
\hline Venezuela & 11 & $27 \%$ & 61 \\
\hline
\end{tabular}


Table 2

OLS Estimates

\begin{tabular}{|c|c|c|c|c|c|c|}
\hline Variable & \multicolumn{2}{|c|}{ Named Imports } & \multicolumn{2}{|c|}{ Non-named Imports } & \multicolumn{2}{|c|}{ Overall Imports } \\
\hline Constant & $\begin{array}{c}1.797 \\
(0.315)^{* * *}\end{array}$ & $\begin{array}{c}1.448 \\
(0.312) * * *\end{array}$ & $\begin{array}{c}0.521 \\
(0.179) * *\end{array}$ & $\begin{array}{c}0.605 \\
(0.174) * * *\end{array}$ & $\begin{array}{c}1.046 \\
(0.202) * * *\end{array}$ & $\begin{array}{c}1.111 \\
(0.198) * * *\end{array}$ \\
\hline $\operatorname{Ln}($ Value in $t-1)$ & $\begin{array}{l}0.899 \\
(0.018)^{* * *}\end{array}$ & $\begin{array}{l}0.908 \\
(0.017) * * *\end{array}$ & $\begin{array}{l}0.942 \\
(0.009) * * *\end{array}$ & $\begin{array}{c}0.945 \\
(0.009) * * *\end{array}$ & $\begin{array}{l}0.921 \\
(0.011)^{* * *}\end{array}$ & $\begin{array}{l}0.922 \\
(0.010) * * *\end{array}$ \\
\hline$\% \Delta$ Value between $t-1$ and $t-2$ & $\begin{array}{l}0.155 \\
(0.037) * * *\end{array}$ & $\begin{array}{l}0.166 \\
(0.036) * * *\end{array}$ & $\begin{array}{l}0.264 \\
(0.027)^{* * *}\end{array}$ & $\begin{array}{c}0.267 \\
(0.026) * * *\end{array}$ & $\begin{array}{l}0.107 \\
(0.016) * * *\end{array}$ & $\begin{array}{l}0.110 \\
(0.016)^{* * *}\end{array}$ \\
\hline Number Named $>=3$ (dummy) & $\begin{array}{c}0.139 \\
(0.082) *\end{array}$ & $\begin{array}{r}0.091 \\
(0.079)\end{array}$ & $\begin{array}{c}0.120 \\
(0.046) * *\end{array}$ & $\begin{array}{c}0.132 \\
(0.044) * *\end{array}$ & $\begin{array}{c}0.097 \\
(0.045) * *\end{array}$ & $\begin{array}{c}0.103 \\
(0.044)\end{array} * *$ \\
\hline $\begin{array}{c}\text { Size of Duty } \\
\operatorname{Ln} \text { (Duty) }\end{array}$ & $\begin{array}{c}-0.055 \\
(0.031)^{*}\end{array}$ & & $\begin{array}{c}0.076 \\
(0.016)^{* * *}\end{array}$ & & $\begin{array}{c}0.051 \\
(0.016)^{* * *}\end{array}$ & \\
\hline Low Duty (dummy) & & $\begin{array}{r}-0.004 \\
(0.121)\end{array}$ & & $\begin{array}{c}-0.120 \\
(0.066)^{*}\end{array}$ & & $\begin{array}{l}-0.146 \\
(0.065) * *\end{array}$ \\
\hline High Duty (dummy) & & $\begin{array}{r}-0.133 \\
(0.129)\end{array}$ & & $\begin{array}{c}0.229 \\
(0.070) * *\end{array}$ & & $\begin{array}{r}0.068 \\
(0.068)\end{array}$ \\
\hline $\begin{array}{l}\text { Cross-effect: Duty }{ }^{*} \text { Decision } \\
\text { Ln(Duty), affirmative }\end{array}$ & $\begin{array}{c}-0.103 \\
(0.040) * *\end{array}$ & & $\begin{array}{r}-0.019 \\
(0.022)\end{array}$ & & $\begin{array}{c}-0.036 \\
(0.021) *\end{array}$ & \\
\hline Low Duty, affirmative (dummy) & & $\begin{array}{r}0.181 \\
(0.157)\end{array}$ & & $\begin{array}{r}0.116 \\
(0.086)\end{array}$ & & $\begin{array}{r}0.115 \\
(0.083)\end{array}$ \\
\hline High Duty, affirmative (dummy) & & $\begin{array}{r}-0.227 \\
(0.162)\end{array}$ & & $\begin{array}{r}-0.098 \\
(0.089)\end{array}$ & & $\begin{array}{r}-0.105 \\
(0.086)\end{array}$ \\
\hline $\begin{array}{l}\text { Years Following } A D \text { petition (dummies) } \\
t+1\end{array}$ & $\begin{array}{l}-0.433 \\
(0.161)^{* *}\end{array}$ & $\begin{array}{c}-0.274 \\
(0.153)^{*}\end{array}$ & $\begin{array}{r}0.074 \\
(0.088)\end{array}$ & $\begin{array}{r}0.094 \\
(0.083)\end{array}$ & $\begin{array}{r}0.022 \\
(0.086)\end{array}$ & $\begin{array}{r}0.067 \\
(0.081)\end{array}$ \\
\hline$t+2$ & $\begin{array}{l}-0.366 \\
(0.161)^{* *}\end{array}$ & $\begin{array}{r}-0.212 \\
(0.153)\end{array}$ & $\begin{array}{c}0.166 \\
(0.089) *\end{array}$ & $\begin{array}{c}0.191 \\
(0.083) * *\end{array}$ & $\begin{array}{r}0.111 \\
(0.087)\end{array}$ & $\begin{array}{c}0.159 \\
(0.081)^{*}\end{array}$ \\
\hline$t+3$ & $\begin{array}{r}-0.266 \\
(0.162)\end{array}$ & $\begin{array}{r}-0.104 \\
(0.153)\end{array}$ & $\begin{array}{l}0.207 \\
(0.090) * *\end{array}$ & $\begin{array}{c}0.232 \\
(0.084) * *\end{array}$ & $\begin{array}{r}0.099 \\
(0.087)\end{array}$ & $\begin{array}{c}0.150 \\
(0.082) *\end{array}$ \\
\hline$t+4$ & $\begin{array}{r}-0.224 \\
(0.162)\end{array}$ & $\begin{array}{r}-0.064 \\
(0.153)\end{array}$ & $\begin{array}{c}0.267 \\
(0.091)^{* *}\end{array}$ & $\begin{array}{c}0.286 \\
(0.085) * * *\end{array}$ & $\begin{array}{c}0.181 \\
(0.087)^{* *}\end{array}$ & $\begin{array}{l}0.227 \\
(0.082) * * *\end{array}$ \\
\hline$t+5$ & $\begin{array}{r}-0.261 \\
(0.165)\end{array}$ & $\begin{array}{r}-0.099 \\
(0.156)\end{array}$ & $\begin{array}{c}0.246 \\
(0.092)^{* *}\end{array}$ & $\begin{array}{c}0.267 \\
(0.086) * *\end{array}$ & $\begin{array}{c}0.187 \\
(0.088)^{* *}\end{array}$ & $\begin{array}{l}0.232 \\
(0.083) * * *\end{array}$ \\
\hline $\begin{array}{c}\text { Cross-effect: Years*Decision } \\
\text { t+1*Affirmative }\end{array}$ & $\begin{array}{r}0.239 \\
(0.198)\end{array}$ & $\begin{array}{r}-0.051 \\
(0.180)\end{array}$ & $\begin{array}{r}-0.065 \\
(0.109)\end{array}$ & $\begin{array}{r}-0.077 \\
(0.099)\end{array}$ & $\begin{array}{r}0.010 \\
(0.105)\end{array}$ & $\begin{array}{r}-0.050 \\
(0.095)\end{array}$ \\
\hline$t+2 *$ Affirmative & $\begin{array}{r}0.002 \\
(0.198)\end{array}$ & $\begin{array}{r}-0.277 \\
(0.181)\end{array}$ & $\begin{array}{c}-0.182 \\
(0.109) *\end{array}$ & $\begin{array}{c}-0.211 \\
(0.099) * *\end{array}$ & $\begin{array}{r}-0.142 \\
(0.106)\end{array}$ & $\begin{array}{l}-0.211 \\
(0.096)^{* *}\end{array}$ \\
\hline$t+3^{*}$ Affirmative & $\begin{array}{r}-0.023 \\
(0.199)\end{array}$ & $\begin{array}{c}-0.316 \\
(0.181)^{*}\end{array}$ & $\begin{array}{r}-0.115 \\
(0.112)\end{array}$ & $\begin{array}{r}-0.153 \\
(0.102)\end{array}$ & $\begin{array}{r}-0.032 \\
(0.108)\end{array}$ & $\begin{array}{r}-0.110 \\
(0.097)\end{array}$ \\
\hline$t+4^{*}$ Affirmative & $\begin{array}{r}-0.096 \\
(0.201)\end{array}$ & $\begin{array}{l}-0.388 \\
(0.183)^{* *}\end{array}$ & $\begin{array}{r}-0.093 \\
(0.113)\end{array}$ & $\begin{array}{r}-0.126 \\
(0.104)\end{array}$ & $\begin{array}{r}-0.040 \\
(0.108)\end{array}$ & $\begin{array}{r}-0.113 \\
(0.099)\end{array}$ \\
\hline$t+5 *$ Affirmative & $\begin{array}{r}-0.033 \\
(0.203)\end{array}$ & $\begin{array}{c}-0.327 \\
(0.187)\end{array}$ & $\begin{array}{r}-0.017 \\
(0.114)\end{array}$ & $\begin{array}{r}-0.051 \\
(0.105)\end{array}$ & $\begin{array}{r}-0.005 \\
(0.109)\end{array}$ & $\begin{array}{r}-0.077 \\
(0.100)\end{array}$ \\
\hline $\begin{array}{l}\text { Adjusted R2 } \\
\text { Number of Obs. }\end{array}$ & $\begin{array}{r}0.758 \\
1164\end{array}$ & $\begin{array}{r}0.753 \\
1214\end{array}$ & $\begin{array}{r}0.927 \\
1157\end{array}$ & $\begin{array}{r}0.931 \\
1207\end{array}$ & $\begin{array}{r}0.912 \\
1195\end{array}$ & $\begin{array}{r}0.918 \\
1245\end{array}$ \\
\hline
\end{tabular}

Standard Errors in parentheses. Calendar year dummies estimated, but not reported.

$* * *, * *$, and $*$ indicate significance at $1 \%, 5 \%$, and $10 \%$, respectively. 
Table 3

Effect of U.S. Antidumping Activity

Countries with the Largest Trade contraction (when named)

\begin{tabular}{|c|c|c|c|c|c|}
\hline & \multicolumn{2}{|c|}{ When named } & \multicolumn{2}{|c|}{ When not named } & \multirow{2}{*}{$\begin{array}{c}\text { Net effect } \\
\Delta \text { imports, } \\
\mathrm{t}_{0} \text { and } \mathrm{t}_{1} \\
\text { (millions } \$ \text { ) }\end{array}$} \\
\hline & $\begin{array}{c}\% \Delta \\
t_{0} \text { and } t_{1}\end{array}$ & $\begin{array}{c}\Delta \text { imports, } \\
\mathrm{t}_{0} \text { and } \mathrm{t}_{1} \\
(\text { millions } \$ \text { ) }\end{array}$ & $\begin{array}{c}\% \Delta \\
t_{0} \text { and } t_{1}\end{array}$ & $\begin{array}{c}\Delta \text { imports, } \\
\text { to }_{0} \text { and } t_{1} \\
(\text { millions } \$ \text { ) }\end{array}$ & \\
\hline Japan & $-20.37 \%$ & $-\$ 7,654$ & $13.46 \%$ & $\$ 5,356$ & $-\$ 2,298$ \\
\hline Brazil & $-13.43 \%$ & $-\$ 201$ & $17.99 \%$ & $\$ 17,962$ & $\$ 17,762$ \\
\hline Italy & $-13.48 \%$ & $-\$ 184$ & $18.31 \%$ & $\$ 19,514$ & $\$ 19,331$ \\
\hline South Korea & $-8.01 \%$ & $-\$ 117$ & $17.62 \%$ & $\$ 19,442$ & $\$ 19,326$ \\
\hline France & $-8.07 \%$ & $-\$ 109$ & $17.94 \%$ & $\$ 20,959$ & $\$ 20,850$ \\
\hline United Kingdom & $-11.56 \%$ & $-\$ 69$ & $18.31 \%$ & $\$ 21,539$ & $\$ 21,470$ \\
\hline Taiwan & $-5.41 \%$ & $-\$ 65$ & $17.29 \%$ & $\$ 20,469$ & $\$ 20,404$ \\
\hline Canada & $-6.31 \%$ & $-\$ 47$ & $18.98 \%$ & $\$ 21,230$ & $\$ 21,183$ \\
\hline USSR & $-25.42 \%$ & $-\$ 44$ & $5.42 \%$ & $\$ 5,767$ & $\$ 5,723$ \\
\hline Iran & $-62.52 \%$ & $-\$ 23$ & $0.11 \%$ & $\$ 19$ & $-\$ 5$ \\
\hline P.R. China & $-14.33 \%$ & $-\$ 23$ & $9.46 \%$ & $\$ 11,062$ & $\$ 11,039$ \\
\hline
\end{tabular}

Countries with the Largest Trade expansion (when not named)

\begin{tabular}{|c|c|c|c|c|c|}
\hline & \multicolumn{2}{|c|}{ When named } & \multicolumn{2}{|c|}{ When not named } & \multirow{2}{*}{$\begin{array}{l}\text { Net effect } \\
\Delta \text { imports, } \\
\text { to }_{0} \text { and } t_{1} \\
\text { (millions } \$ \text { ) }\end{array}$} \\
\hline & $\begin{array}{c}\% \Delta \\
t_{0} \text { and } t_{1}\end{array}$ & $\begin{array}{c}\Delta \text { imports, } \\
\mathrm{t}_{0} \text { and } \mathrm{t}_{1} \\
\text { (millions } \$ \text { ) }\end{array}$ & $\begin{array}{c}\% \Delta \\
\mathrm{t}_{0} \text { and } \mathrm{t}_{1}\end{array}$ & $\begin{array}{c}\Delta \text { imports, } \\
t_{0} \text { and } t_{1} \\
(\text { millions } \$ \text { ) }\end{array}$ & \\
\hline Belgium & $-6.14 \%$ & $-\$ 1$ & $18.12 \%$ & $\$ 23,110$ & $\$ 23,109$ \\
\hline Netherlands & $-13.99 \%$ & $-\$ 4$ & $18.05 \%$ & $\$ 23,088$ & $\$ 23,084$ \\
\hline Austria & -- & -- & $18.25 \%$ & $\$ 22,798$ & $\$ 22,798$ \\
\hline Switzerland & --- & --- & $17.88 \%$ & $\$ 22,783$ & $\$ 22,783$ \\
\hline Australia & $-26.00 \%$ & $-\$ 2$ & $17.92 \%$ & $\$ 22,558$ & $\$ 22,556$ \\
\hline Spain & $-8.56 \%$ & $-\$ 14$ & $17.98 \%$ & $\$ 22,370$ & $\$ 22,356$ \\
\hline Denmark & --- & --- & $17.84 \%$ & $\$ 22,220$ & $\$ 22,220$ \\
\hline Mexico & $2.74 \%$ & $\$ 4$ & $17.91 \%$ & $\$ 21,745$ & $\$ 21,749$ \\
\hline United Kingdom & $-11.56 \%$ & $-\$ 69$ & $18.31 \%$ & $\$ 21,539$ & $\$ 21,470$ \\
\hline Hong Kong & $3.33 \%$ & $\$ 3$ & $17.87 \%$ & $\$ 21,533$ & $\$ 21,536$ \\
\hline
\end{tabular}


Figure 1

Value of Imports (named country)




Figure 2

Value of Imports (named country)

Case Rejected

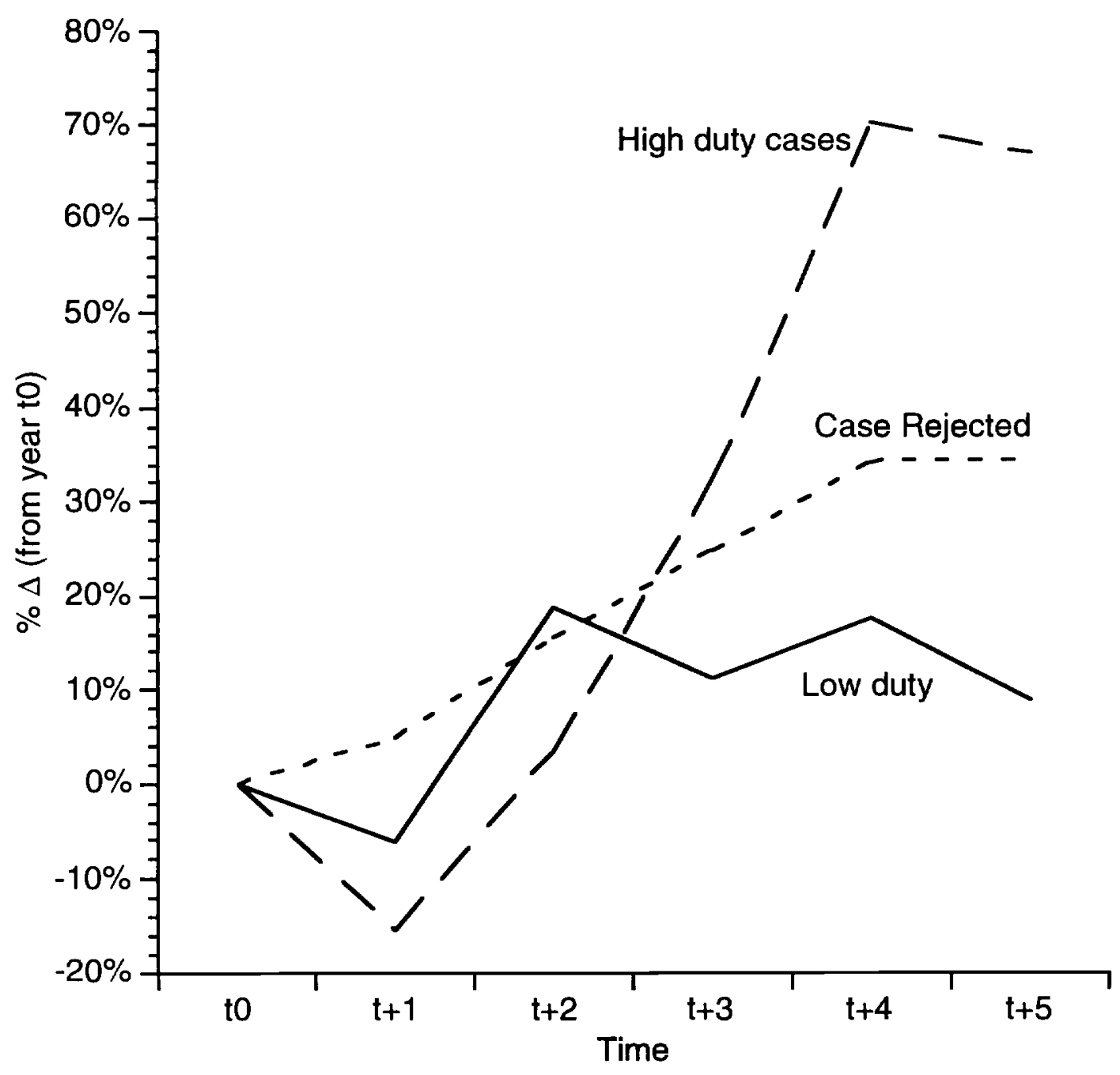


Figure 3

Value of Imports (non-named countries)

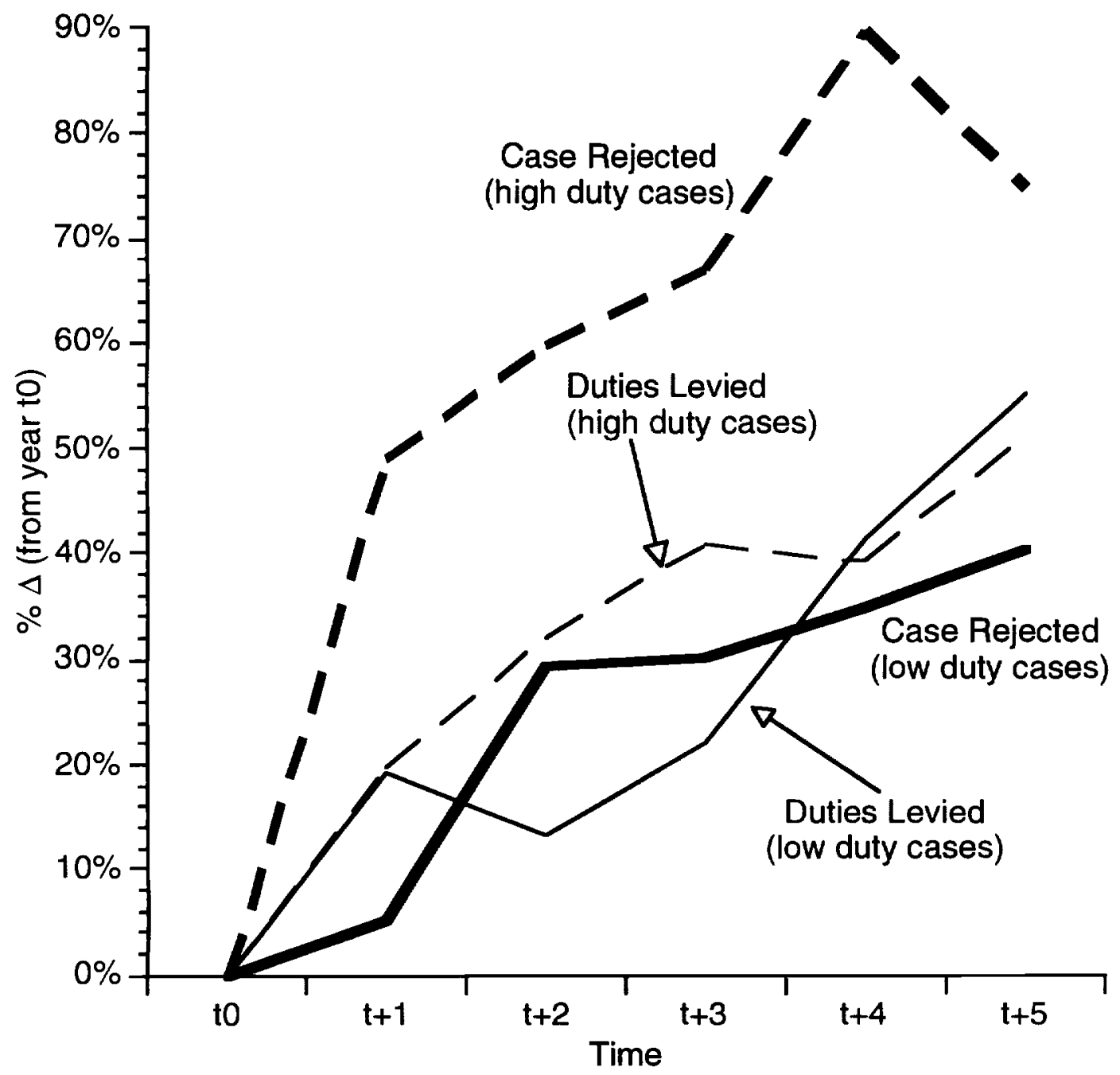


Figure 4

Value of Imports (non-named countries)

Duties Levied

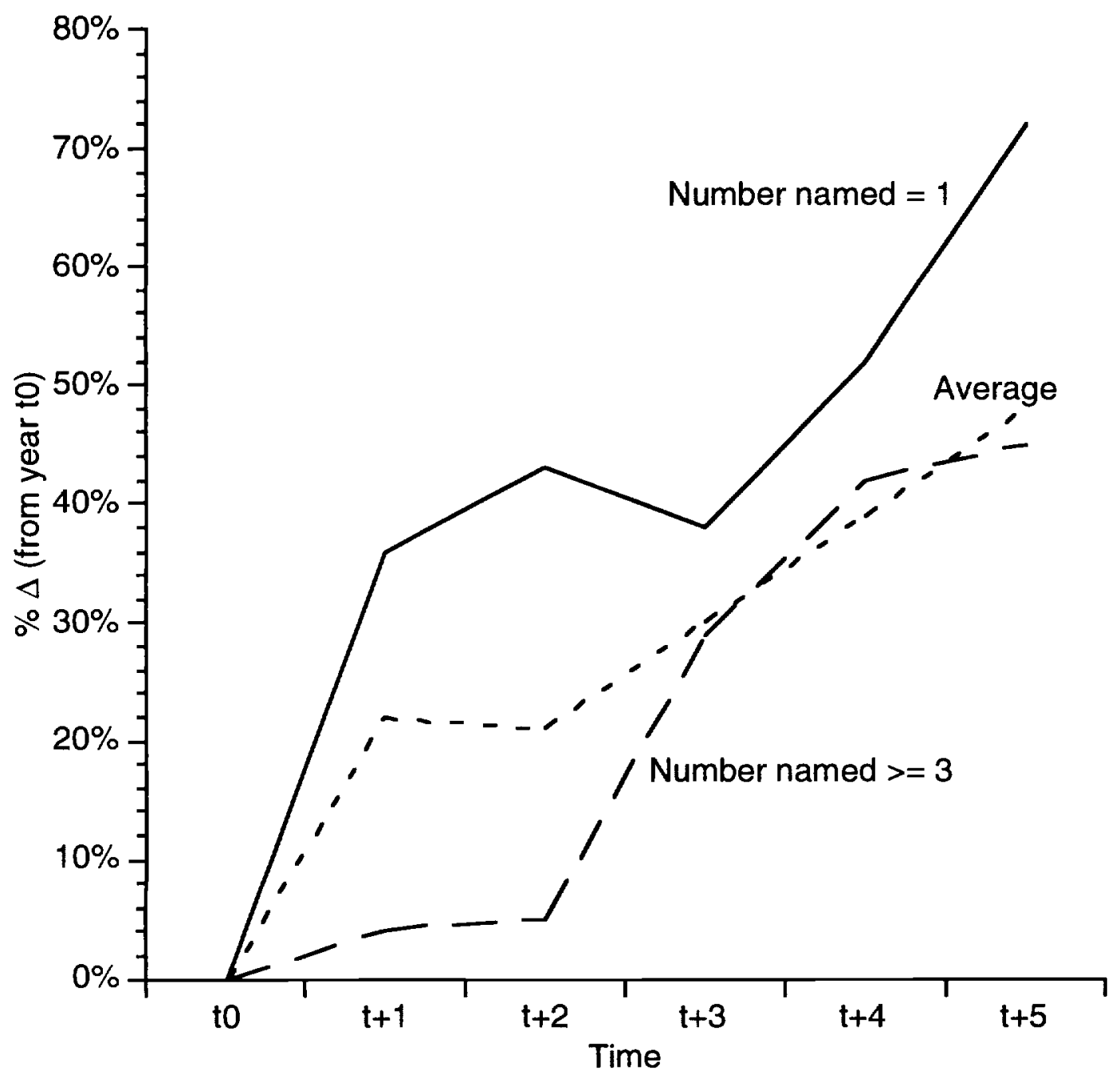


Figure 5

Value of Imports (named vs. total)

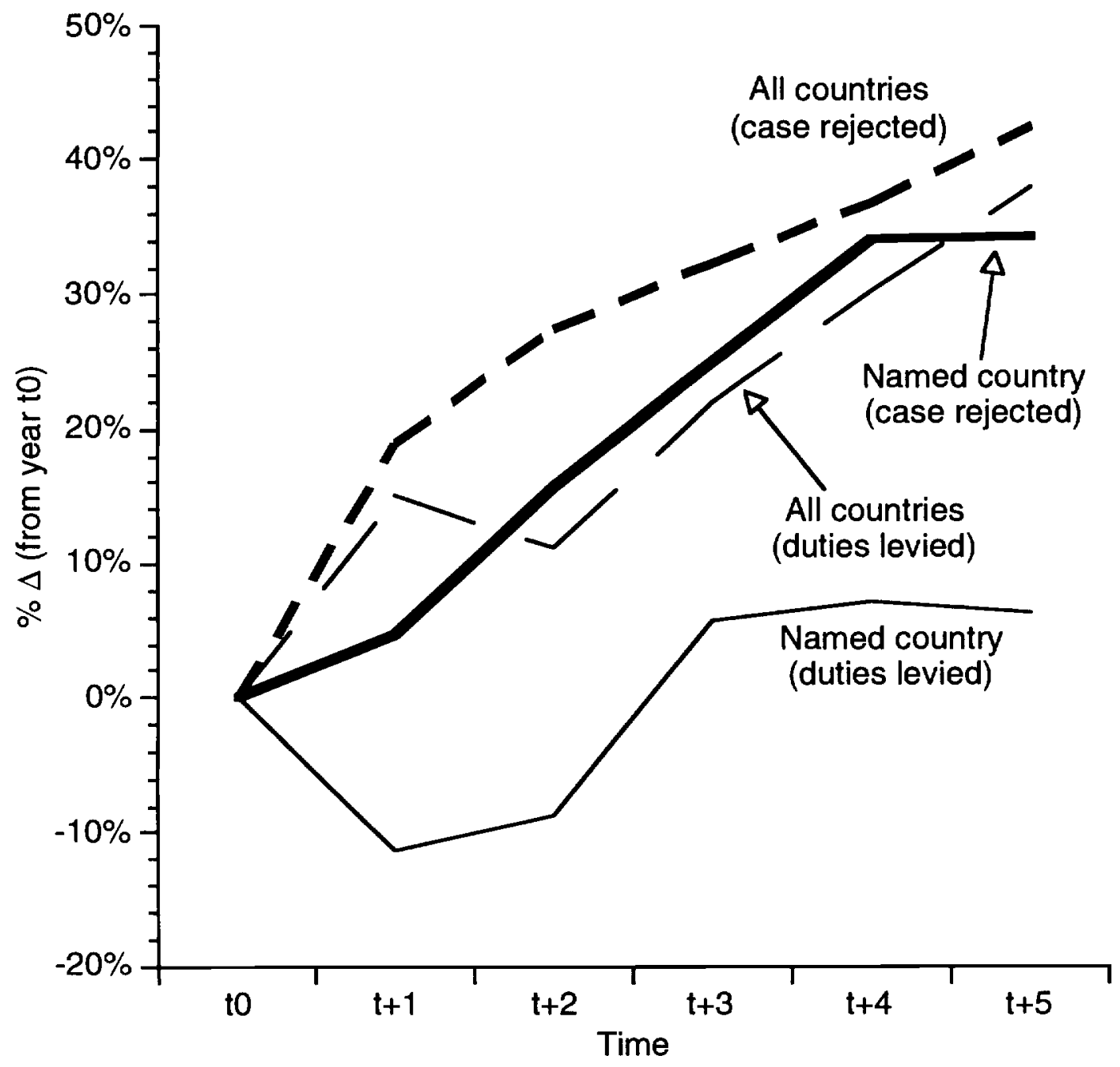


Figure 6

Value of Imports (total)

Duties Levied

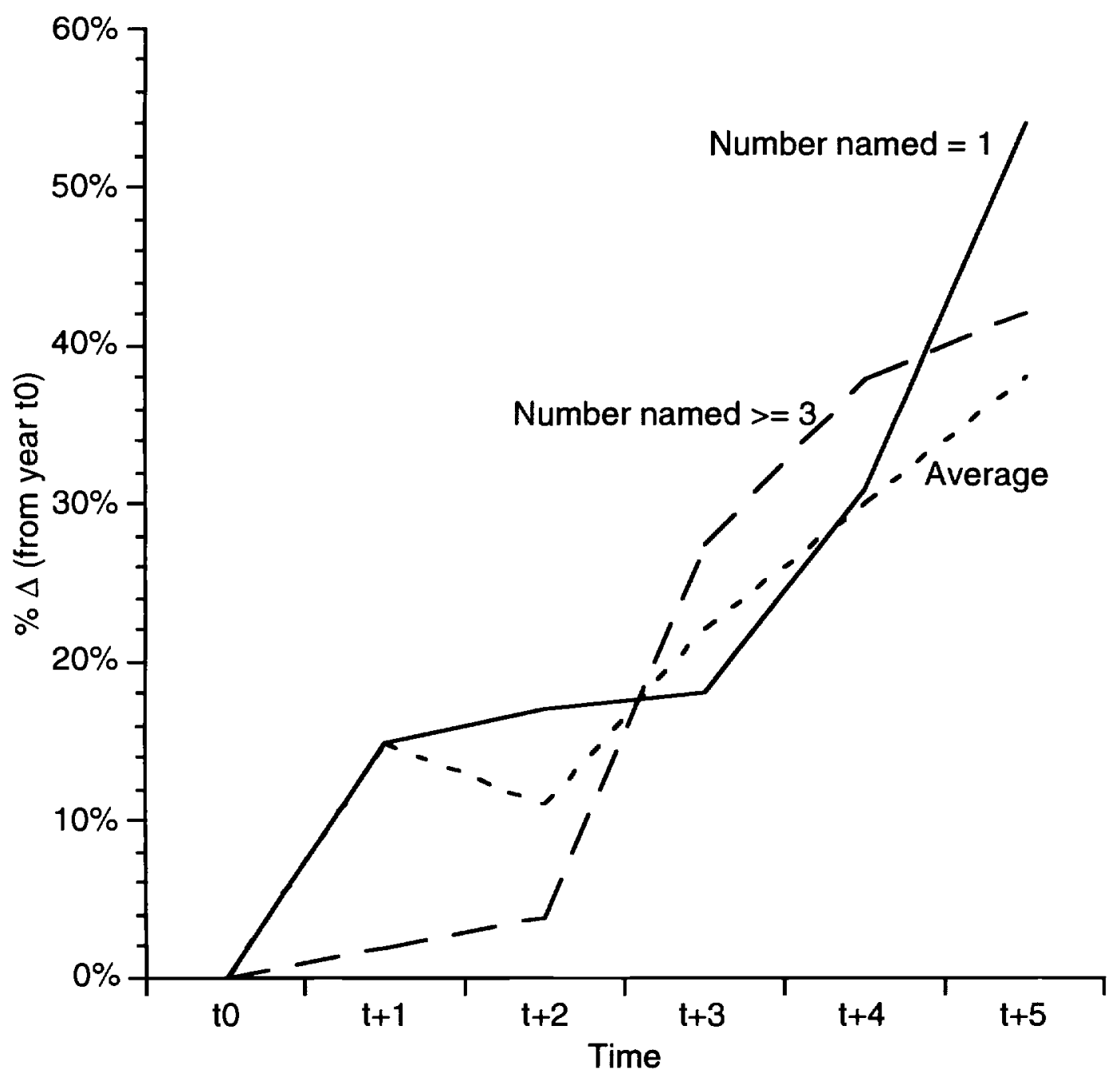




\section{Figure 7 \\ Unit Value (named country)}

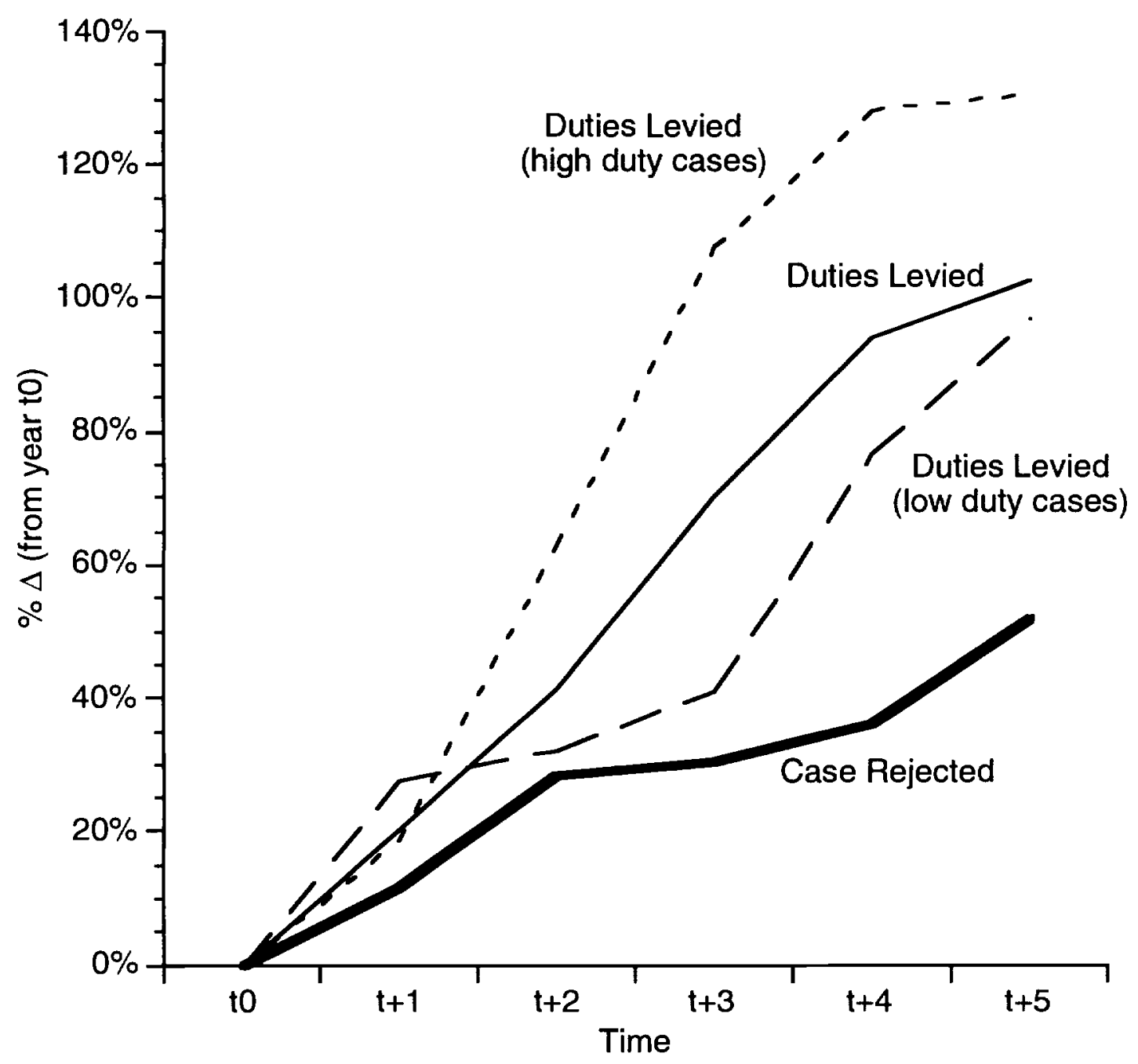


Figure 8

Quantity (named country)

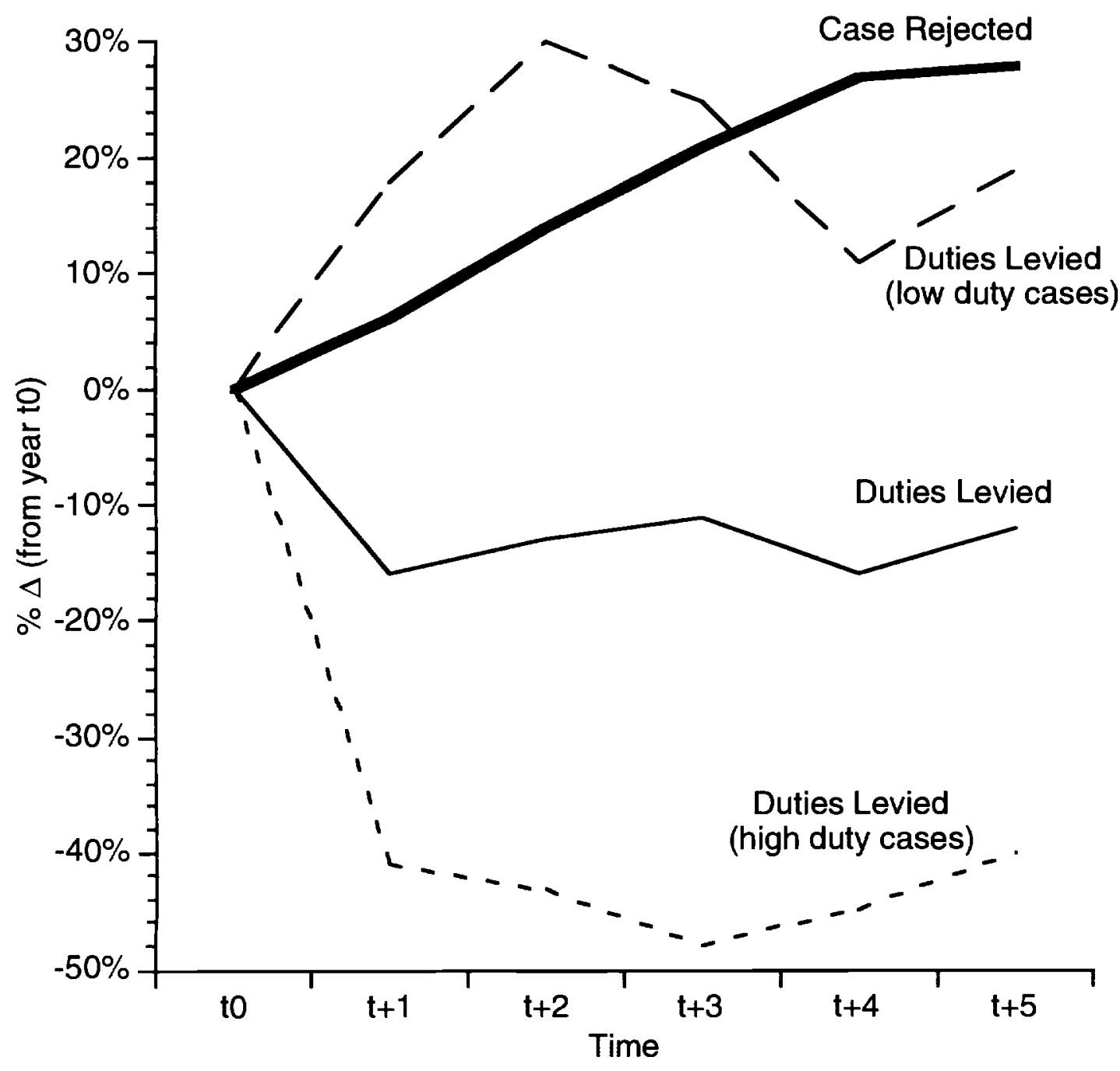


Figure 9

Unit Value (named vs. non-named)

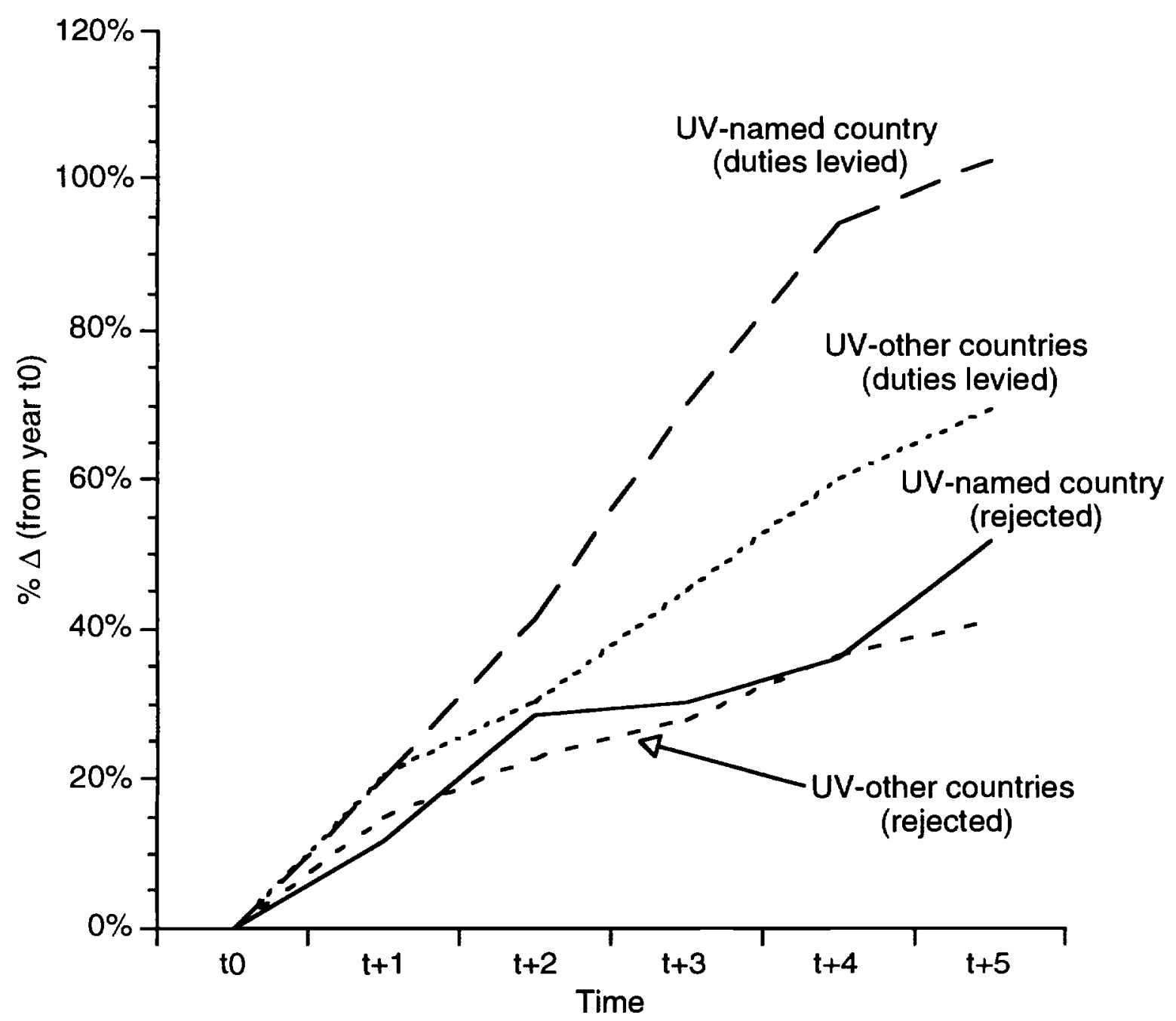


Figure 10

Unit Value (named country)

Duties Levied

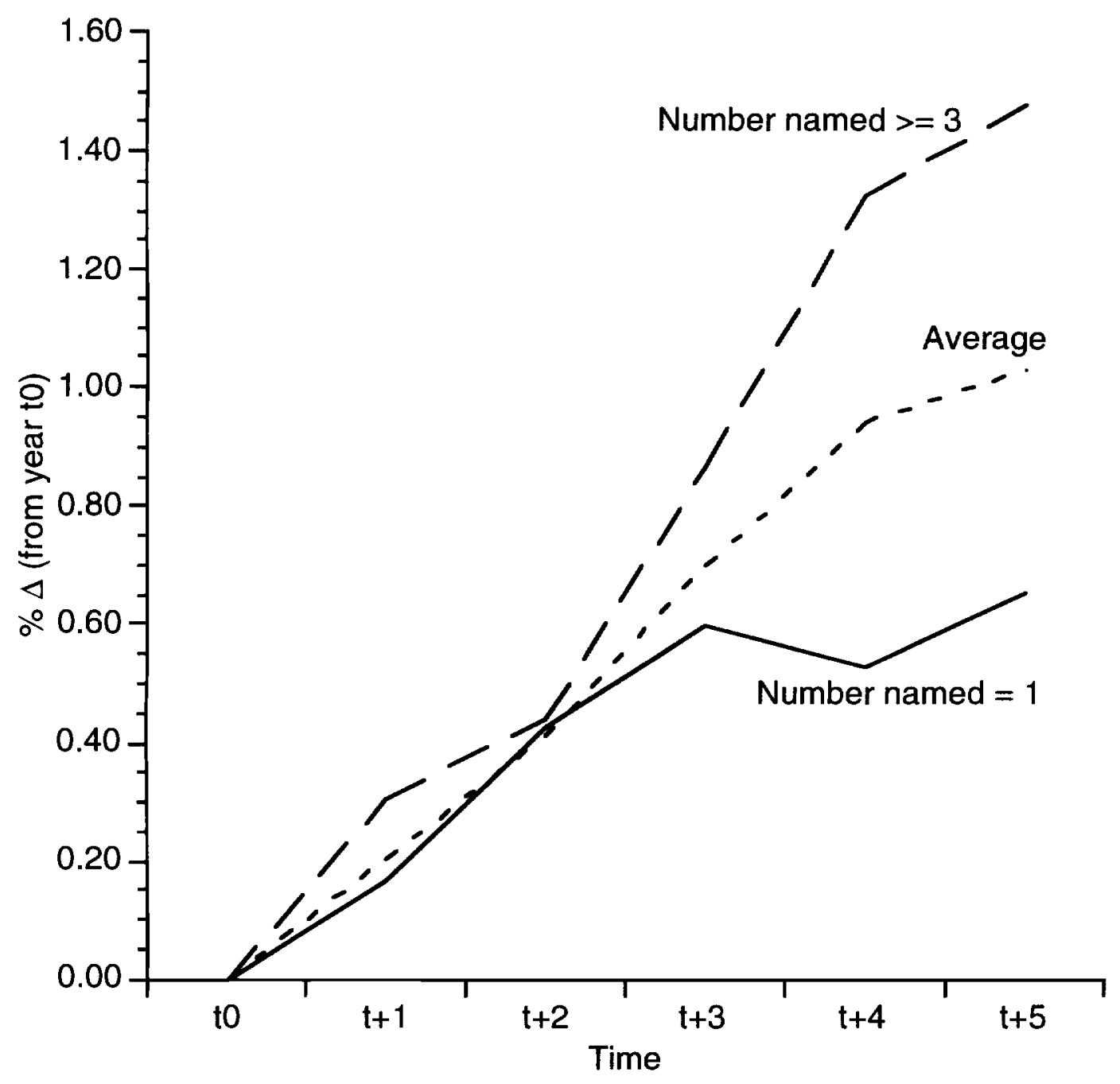

